\title{
How optimal cash changed by the global financial crisis? A multi-country analysis
}

\author{
Hasan Tekin* \\ Karabuk University, Turkey
}

Received: 30 September 2019

Revised: 29 January 2020

Accepted: 30 January 2020

\begin{abstract}
This article investigates the impact of the global financial crisis 2007-2009 (GFC) as well as financial constraints and governance on optimal cash decisions. Using 14,885 sample firms from eleven countries, empirical results show that constrained firms have a faster cash adjustment than unconstrained firms as confirmed by precautionary motive. Contrary to agency motive, firms in weak-governed countries have a slower cash adjustment than those in well-governed countries before the GFC. However, this picture changes after the GFC. Specifically, they increase their cash adjustments, whereas those in well-governed countries decrease their cash adjustments as supported by agency motive. Overall, optimal cash policy differs following the GFC across financial constraints and governance.
\end{abstract}

Keywords: adjustment speed; agency motive; financial constraints; global financial crisis; governance; precautionary motive

JEL Classification Codes: C23, G01, G34, G38

\section{Introduction}

Cash retention is used as a hedging instrument against financial risk when external financing is costly during turbulence. Chen et al. (2018) argues an uncertainty occurs and the demand for cash becomes important for firms. Grounded in precautionary motive, smaller or financially constrained firms accumulate more cash to mitigate difficulties in a period of crisis. Based on agency motive, firms in weak-governed countries hold higher cash than those in well-governed countries. Since the global financial crisis 2007-2009 (GFC) gives a natural experiment opportunity, this research analyses how the trend of optimal cash holdings changes as an outcome of the GFC across the variation in financial constraints and governance.

Previous research examines how the GFC affects corporations' cash decisions (Chen et al. 2018; Martinez-Sola et al. 2018); so far, there has been no agreement on the critical issue of how optimal cash decisions have changed after the financial crisis. While the literature recently finds that smaller or financially constrained firms have a faster adjustment speed of cash than larger

\footnotetext{
*E-mail: hasantekin85@gmail.com.
}

Citation: Tekin, H. (2020) How optimal cash changed by the global financial crisis? A multi-country analysis, Economics and Business Letters, 9(2), 114-123.

DOI: 10.17811/ebl.9.2.2020.114-123 
or unconstrained firms (Lozano and Duran 2017; Martinez-Sola et al. 2018); nevertheless, the optimal cash holdings have not been sufficiently and empirically studied across financial constraints and governance in the aftermath of the GFC.

This study investigates, for the first time, the optimal cash holdings in the post-GFC period. Notably, constrained firms have a faster speed of adjustment (SOA) of cash than unconstrained firms as in line with the precautionary motive. Besides, firms in well-governed countries close the gap between actual and target cash holdings faster than those in weak-governed countries before the GFC as opposed to agency motive. During the post-crisis, they decrease their cash adjustments, but those in weak-governed countries increase the SOA of cash as confirmed by agency motive.

This research contributes to the literature in two ways. First, Martinez-Sola et al. (2018) analyze the optimal cash during the GFC for Spanish small and medium-sized firms, but this study first examines the optimal cash decisions across a cross-country for listed companies after the GFC. Next, the more recent research (Seifert and Gonenc 2018) investigates the role of the Worldwide Governance Indicators (WGI) of Kaufmann et al. (2011) on cash holdings across the globe, whereas no single study has been yet divided its sample and examined the optimal cash holdings across WGI-country governance before and after the GFC.

\section{Optimal Cash Holdings and the Financial Crisis}

\subsection{Theoretical Background}

The precautionary motive focuses on holding more cash to cope with difficulties in accessing finance when asymmetric information and agency costs of debt arise (Ozkan and Ozkan 2004). During a financial crisis, the precautionary motive may be more visible due to increasing information asymmetry, as shown by Chen et al. (2018) for US firms at the time of dot-com crisis and the GFC. When countries in which governance is weak and capital markets are unfavourable to new funding, the precautionary motive, which results in accumulating is more when borrowing is less, would make significance. Besides, La Porta et al. (2000) show that the manager-shareholder conflict occurs when the manager holds cash due to poor investment opportunities rather than disgorging cash to shareholders. They also find that the firm's ownership structure is important for the disbursement of cash; that is why they mention that countries in concentrated ownership and family groups' ownership have weak shareholder rights due to large shareholderminority shareholder conflict.

The optimal amount of cash holdings is also crucial for the trade-off between benefits and costs adjusting cash retention as has been found by empirical research (Ozkan and Ozkan 2004; Bates et al. 2018; Nguyen 2019). However, firms may face different cost levels when carrying cash due to the actual cash amount, whereas it can be difficult to adjust their cash level.

Therefore, the adjustment speed of cash holdings varies across firms and time. Firms need to adjust their cash towards the target cash in time; that is why a partial adjustment may be necessary. Thus, the partial adjustment model of Ozkan and Ozkan (2004) is used to examine the cash holdings' adjustments, as the more recent research does (Lozano and Duran 2017; Bates et al. 2018; Martinez-Sola et al. 2018; Nguyen 2019).

\subsection{Financial Constraints}

The optimal cash level varies across financial constraints. Since financially constrained firms have difficulties in accessing the external finance, they prefer to accumulate liquidity to mitigate possible future shocks and easily make adjustment on their optimal level of cash. For example, Lozano and Duran (2017) comment on how family firms adjust their cash towards the targetcash faster by $3 \%$ than non-family firms because family firms have greater cash than non-family firms. Furthermore, Nguyen (2019) finds that the SOA of firms with above-target cash holdings are relatively faster than those with below-target cash holdings. In this case, the cash level easily allows to adjust toward target cash holdings. 
However, unconstrained firms can increase hoarding cash after a point of macroeconomic shock, while constrained firms still face the severity of the shock; that is why the SOA for unconstrained firms may slightly rise during the recession (Chen et al. 2018). After the GFC, constraint firms tend to have faster cash adjustments than unconstrained firms as precautionary motive suggests, but the SOA of cash may decrease in the post-GFC period compared to the preGFC period because of rising adjustment costs. Therefore, the first hypothesis as follows:

Hypothesis 1: The speed at which constrained firms adjust to the target decreases less than unconstrained firms after the financial crisis.

\subsection{Governance}

Previous research shows that a negative relationship exists between cash holdings and governance (Seifert and Gonenc 2018). In other words, since firms in weak-governed countries face more agency costs, they hold more cash due to the agency motive. To date, no empirical study has analyzed the cash-governance relationship in the GFC context using dynamic panels. An exception is the research of Lozano and Duran (2017) test the optimal level of cash holdings across 16 European countries but they restrict their focus to family control, excluding time variation. They use the interaction effect between family firms and the revised anti-director rights. They find family firms in well-governed countries have a faster speed of adjustment of cash than those in weak-governed countries contrary to the agency motive.

In the post-GFC, firms in well-governed countries which are European countries, are also affected by the Eurozone debt crisis between 2010 and 2012; thus, they may increase borrowing instead of accumulating. Thus, firms in weak-governed countries increase their SOA of cash after the GFC, whereas it is vice versa for those in well-governed countries, which is the result of agency motive. Because firms in weak-governed countries higher cost of carrying cash, since they face difficulties in accessing external finance contrary to those in well-governed countries. Accordingly, the second hypothesis is to be tested:

Hypothesis 2: The speed at which firms in weak-governance countries adjusts to the target increases after the financial crisis, vice versa for those in well-governance countries.

\section{Empirical Model}

This research uses the partial adjustment model, as employed by recent research to test hypotheses (Ozkan and Ozkan 2004; Lozano and Duran 2017; Bates et al. 2018; Martinez-Sola et al. 2018; Nguyen 2019). The procedure of partial adjustment model is stated below:

$$
\mathrm{CASH}_{i, t}-\mathrm{CASH}_{i, t-1}=\lambda_{i}\left(\mathrm{CASH}_{i, t}{ }^{*}-\mathrm{CASH}_{i, t-1}\right)+\varepsilon_{i, t}
$$

where $C A S H_{i, t}$ is the cash ratio of firm $i$ in year $t, \lambda_{i}$ is the adjustment parameter and $\varepsilon_{i t}$ is the timevarying disturbance term.

$$
C A S H_{i, t}{ }^{*}=\beta X_{i, t-1}
$$

where $\mathrm{CASH}_{i, t}{ }^{*}$ is a target cash ratio, $\beta$ is a coefficient vector and $X_{i, t-l}$ is a vector of firm characteristics considering the costs and benefits of cash holdings at time $t-1$.

After the substitution and rearrangement of Equations 1 and 2, the dynamic partial adjustment cash model is as follows:

$$
\mathrm{CASH}_{i, t}=\left(1-\lambda_{i}\right) \mathrm{CASH}_{i, t-1}+(\lambda \beta) X_{i, t-1}+\alpha_{i} F_{i}+\alpha_{t} Y_{t}+\varepsilon_{i, t}
$$

where $\lambda$ is the adjustment speed.

The full dynamic model is stated below:

$$
\begin{gathered}
C A S H_{i j, t}=\left(1-\lambda_{i j}\right) C A S H_{i j, t-l}+ \\
\left(\lambda_{j} \beta_{j}\right)[S I Z E+G R O W+V O L+I N V+L E V+N W C+C F A+R \& D]_{i, t-1}+\alpha_{i j} F_{i}+\alpha_{t} Y_{t}+\varepsilon_{i j, t}
\end{gathered}
$$

where $\mathrm{CASH}_{i, t}$ and $\mathrm{CASH}_{i, t-l}$ are cash and short-term investments to total assets for firm $i$ at time 
$t$ and $t-1$, respectively. Eight control explanatory variables ${ }^{1}$ included. $S I Z E_{i, t-l}$ is lagged firm size, $G R O W_{i, t-1}$ is lagged growth, $V O L_{, t-1}$ is lagged cash flow volatility, $I N V_{i, t-1}$ is lagged investment, $L E V_{i, t-l}$ is lagged leverage, $N W C_{i, t-l}$ is lagged net working capital, $C F A_{i, t-l}$ is lagged cash flow, $R \& D_{i, t-1}$ is lagged R\&D expenses. $F_{i}$ and $Y_{t}$ are firm- and year-fixed effects that control for unobservable factors that affect the cash ratio and $\varepsilon_{i, t}$ is the error term.

When the partial adjustment model includes the lagged dependent variable, common panel methods may not give reliable results due to biased coefficient estimates; that is why the literature develops the methods of instrumental variables ${ }^{2}$ and bias-corrected ${ }^{3}$. Consequently, considering the dynamic panel strategy, this study can use an instrumental variable, the generalized method of moments (GMM) estimators or least square dummy variable correction- LSDVC, but the empirical evidence compares and prefers the system GMM of Blundell and Bond (1998) or LSDVC of Bruno (2005) as the most reliable estimator (Flannery and Hankins 2013; Dang et al. $2015)$ in respect of the nature of panel data.

After performing the analytical correction of the fixed-effects' bias, as called the least square dummy variable-LSDV, Bruno (2005) develops the least square dummy variable correctionLSDVC. To overcome the bias, the LSDVC is preferable to GMM estimators as shown by previous research (Flannery and Hankins 2013; Dang et al. 2015). Therefore, the LSDVC is used due to its reliability and usefulness ${ }^{4}$.

\section{Data}

The sample of 122,787 firm-years is drawn representing 14,885 sample firms from Worldscope in Datastream $^{5}$ for the period 2001-2015. Eleven countries are selected according to their ownership structures ${ }^{6}$ at country-level. Notably, (i) France, Germany, Netherlands and Turkey; (ii) India, Indonesia, Italy, Japan and Korea; and (iii) the UK and the US are chosen as concentrated-, family-, and dispersed-ownership, respectively.

The construction of the sample as follows. First, financial and utility firms are eliminated (Nguyen 2019). To have the conditions of a dynamic panel model, the firms that have observations at least four consecutive years for each subperiod are kept as Coldbeck and Ozkan (2018) do. Last, all continuous variables are winsorized at $1 \%$ and $99 \%$ to mitigate the outlier effect in the sample (Seifert and Gonenc 2018).

All variables are described in Table 1. Tables A1, A3 and A4, in Appendix A, report the (i) sample composition and mean cash across country and year, (ii) descriptive statistics and (iii) correlation matrices, respectively.

Since this study aims to show the role of financial constraints and governance on cash holdings, the sample is also divided by dividend payers dummy and governance. First, the unconstrained firms are defined as dividend payers (DPS), which equals to one; otherwise, the constrained firms are dividend nonpayers, which equals to zero, as accepted in the empirical research (Bates et al. 2018).

\footnotetext{
${ }^{1}$ In corporate finance literature, the one year lagged of explanatory variables is also used to decline any simultaneity bias in dynamic panel analyses (D'Amato 2019:18).

${ }^{2}$ The methods of instrumental variables are (i) instrumental variables, (ii) the first-difference generalised method of moments-GMM, (iii) the system GMM and (iv) the long-difference GMM.

${ }^{3}$ The bias-corrected methods are (i) the least square dummy variable correction-LSDVC, (ii) bootstrap-based correction-BBC and (iii) indirect inference-II.

${ }^{4}$ I do not use the system GMM since it is a costly estimator for this study, Because twelve sub-datasets exist, it can be difficult to mention one proper model for all models that should not simultaneously reject both AR (2) as the null of no residual serial correlation and Hansen tests as the value of GMM function on parameter estimation.

${ }^{5}$ Firm-specific factors are retrieved from Worldscope in Datastream as the more recent research does (Lozano and Duran 2017; Seifert and Gonenc 2018; Nguyen 2019).

${ }^{6}$ While dispersed ownership countries face shareholder-manager problems, concentrated and family groups ownership countries face large shareholder-minority shareholder problems. Regarding the sample selection, these differences in ownership structure are considered and may capture various agency problems at country-level.
} 
Table 1. Data Descriptions.

\begin{tabular}{|c|c|}
\hline Variables & "Variable Descriptions by Worldscope Item \\
\hline$\overline{\mathrm{CASH}}$ & Cash and short-term investments (WC02001) / Total assets (WC02999) \\
\hline L.CASH & Lagged CASH \\
\hline$D P S$ & $\begin{array}{l}\text { Dummy variable is } 1 \text { for dividend payers (unconstrained firms) in the current year, otherwise } \\
0\end{array}$ \\
\hline$G O V$ & $\begin{array}{l}\text { Annual average score of the mean of six governance indicators [(control of corruption }+ \\
\text { government effectiveness }+ \text { political stability }+ \text { rule of law }+ \text { regulatory quality }+ \text { voice } \\
\text { and accountability) / 6] }\end{array}$ \\
\hline L.SIZE & The log of total assets (WC02999) by converting to US dollars year by year. \\
\hline L.GROW & $\begin{array}{l}\text { [Total assets (WC02999) - Book value of equity (WC03501) + Market value of equity } \\
\text { (WC08001)] / Total assets (WC02999) }\end{array}$ \\
\hline L.VOL & The average standard deviation of cash flow of each industry \\
\hline L.INV & Capital expenditures (WC04601) / Total assets (WC02999) \\
\hline L.LEV & Total debt (WC03255) / Total assets (WC02999) \\
\hline \multirow[t]{2}{*}{ L.NWC } & $\begin{array}{l}\text { [Current assets (WC02201) - Current liabilities (WC03101) - Cash and short-term invest- } \\
\text { ments }\end{array}$ \\
\hline & (WC02001)] / Total assets (WC02999) \\
\hline L.CFA & [Pre-tax income (WC01401) + Depreciation (WC01151)] / Total assets (WC02999) \\
\hline$L . R \& D$ & Research and development expense (WC01201) / Net sales (WC01001) \\
\hline$P R E$ & Dummy variable is 1 for the years of $2001-2006$, otherwise 0 \\
\hline CRISIS & Dummy variable is 1 for the years of $2007-2009$, otherwise 0 \\
\hline POST & Dummy variable is 1 for the years of $2010-2015$, otherwise 0 \\
\hline
\end{tabular}

Next, governance (GOV) is calculated as the annual average score of six governance indicators (control of corruption, government effectiveness, politic stability, rule of law, regulatory quality, voice and accountability) as recently employed by Seifert and Gonenc (2018). GOV takes a negative or positive value depending on the governance level of countries and fluctuates from weakto well-governance. Also, the sample is divided as weak governance and well governance below and above the median of the annual governance year by year (Lozano and Duran 2017).

\section{Empirical Results}

The SOA is calculated as follows: "1 minus the coefficient of the lagged cash ratio". The model includes the lagged cash and control firm-level variables. As the robust estimator, the LSDVC is employed following Dang et al. (2015) that support the earlier findings reached by Flannery and Hankins (2013).

Optimal cash holdings are investigated to understand how optimal cash holdings differ by the existence of financial constraints and governance across the pre-crisis, crisis and post-crisis periods in Table 2. Previous research mentions that the SOA differs across the financial constraints. Lozano and Duran (2017), for example, report that family firms which are financially more constrained, adjust their cash ratio towards the target cash level 3\% quicker than non-family firms do.

However, the picture differs during and after the GFC. As pointed out by Chen et al. (2018), unconstrained firms have pre-saved cash just after the 2000 dot-com crisis-before the GFC-, but constrained firms face more problems during this period. Since financially constrained firms drop their SOA of cash by $2.1 \%$, unconstrained firms slightly rise their SOA by $0.5 \%$ during turbulence. However, financially constrained-dividend nonpayer- firms have slower cash adjustment towards target cash with 50.1\% compared to the pre-GFC period, the SOA of cash is more slowly for financially unconstrained-dividend payer- firms with $16.6 \%$ in the post-GFC, as in line with precautionary motive. Notably, constrained firms decrease their cash adjustments less by $15.9 \%$ than unconstrained firms from pre- to the post-GFC period. Therefore, Hypothesis 1 is not rejected.

Considering the time differences, this study examines cash adjustments across the level of governance as an original first-time approach in the literature. Contrary to agency motive, the findings in columns 7 and 10 for the pre-crisis and in columns 8 and 11 for the crisis period show 
that the firms in well-governed countries have higher cash adjustments by $10.8 \%$ and $0.1 \%$ than for those in weak-governed countries before and during the GFC, respectively. Nevertheless, firms in Germany, Netherlands and the UK, as well-governed European countries, and those in France and Italy, as weak-governed European countries in sample over 2010-2015 have also faced the Eurozone debt crisis (2010-2012). Results show that firms in weak-governed countries increase their cash adjustments by $14.3 \%$, whereas those in well- governed countries decrease by $7.0 \%$, which supports the agency motive. Consequently, Hypothesis 2 is not rejected. Besides, the firm-level control variables ${ }^{7}$ of cash vary across financial constraints and governance for subperiods-pre-crisis, crisis and post-crisis.

Regarding the robustness checks, I do some additional tests whether to check the results are robustness or not, as shown in Appendix A (Table A2). First, as the alternative measure of main variables, I use the firm size for financial constraints (Martinez-Sola et al. 2018) and the revised Antidirector rights for governance (Seifert and Gonenc 2018) in Panel A. Next, I exclude firms in two highest proportion of countries: Japan and the US in Panel B, then firms in five highest proportion of countries: India, Japan, Korea, the UK and the US from the whole sample for the sample composition. Finally, I employ the system GMM in Panel D, as the literature commonly uses (Ozkan and Ozkan 2004; Bates et al. 2018; Nguyen 2019). The robustness results are qualitatively similar to the main results.

Table 2. Optimal Cash Holdings across Financial Constraints and Governance.

\begin{tabular}{|c|c|c|c|c|c|c|}
\hline \multicolumn{7}{|c|}{$\begin{array}{l}\overline{\text { Panel A. Financial Constraints }} \\
\text { Dependent variable: CASH }\end{array}$} \\
\hline & \multicolumn{2}{|c|}{ Constrained firms } & & \multicolumn{3}{|c|}{ Unconstrained firms } \\
\hline & $\overline{P R E}$ & CRISIS & POST & $\overline{P R E}$ & CRISIS & POST \\
\hline & 2001-2006 & 2007-2009 & $2010-2015$ & 2001-2006 & 2007-2009 & $2010-2015$ \\
\hline Variables & (1) & (2) & (3) & (4) & $(5)$ & $(6)$ \\
\hline \multirow[t]{2}{*}{ L.CASH } & $0.391 * * *$ & $0.412 * * *$ & $0.499 * * *$ & $0.572 * * *$ & $0.567 * * *$ & $0.834 * * *$ \\
\hline & $(0.032)$ & $(0.005)$ & $(0.004)$ & $(0.007)$ & $(0.001)$ & $(0.007)$ \\
\hline$\lambda$ & $60.9 \%$ & $58.8 \%$ & $50.1 \%$ & $42.8 \%$ & $43.3 \%$ & $16.6 \%$ \\
\hline \multicolumn{7}{|l|}{ Controls } \\
\hline \multirow[t]{2}{*}{ L.SIZE } & $-0.023 * * *$ & $-0.020 * *$ & -0.016 & -0.003 & $-0.020 * * *$ & $0.014 * * *$ \\
\hline & $(0.008)$ & $(0.010)$ & $(0.013)$ & $(0.006)$ & $(0.001)$ & $(0.003)$ \\
\hline \multirow[t]{2}{*}{ L.GROW } & $0.004 * * *$ & $0.003 * *$ & $0.004 * * *$ & -0.000 & -0.002 & $0.001 * *$ \\
\hline & $(0.000)$ & $(0.001)$ & $(0.001)$ & $(0.001)$ & $(0.004)$ & $(0.000)$ \\
\hline \multirow[t]{2}{*}{ L.VOL } & $-3.082 * *$ & 5.165 & 0.034 & $-2.177 * * *$ & 2.633 & 0.444 \\
\hline & $(1.270)$ & $(4.898)$ & $(0.595)$ & $(0.186)$ & $(2.281)$ & $(0.880)$ \\
\hline \multirow[t]{2}{*}{ L.INV } & -0.034 & $0.047 * * *$ & $-0.035 * * *$ & $-0.033 * * *$ & 0.020 & -0.025 \\
\hline & $(0.064)$ & $(0.013)$ & $(0.013)$ & $(0.000)$ & $(0.030)$ & $(0.022)$ \\
\hline \multirow[t]{2}{*}{ L.LEV } & -0.002 & $0.019 * * *$ & $0.026^{*}$ & $0.015 * * *$ & -0.012 & -0.006 \\
\hline & $(0.008)$ & $(0.002)$ & $(0.014)$ & $(0.002)$ & $(0.008)$ & $(0.032)$ \\
\hline \multirow[t]{2}{*}{ L.NWC } & 0.005 & $0.045 * * *$ & 0.010 & $0.110 * * *$ & $0.125 * * *$ & $0.131 * * *$ \\
\hline & $(0.004)$ & $(0.002)$ & $(0.014)$ & $(0.005)$ & $(0.027)$ & $(0.006)$ \\
\hline \multirow[t]{2}{*}{ L.CFA } & $-0.022 * *$ & 0.004 & $-0.022 * *$ & 0.018 & -0.005 & -0.018 \\
\hline & $(0.009)$ & $(0.010)$ & $(0.009)$ & $(0.013)$ & $(0.021)$ & $(0.036)$ \\
\hline \multirow[t]{2}{*}{$L . R \& D$} & 0.012 & $0.145 * * *$ & $-0.007 * * *$ & -0.031 & $-0.245 * * *$ & $-0.099 * * *$ \\
\hline & $(0.015)$ & $(0.023)$ & $(0.001)$ & $(0.032)$ & $(0.086)$ & $(0.021)$ \\
\hline Firm FE & Yes & Yes & Yes & Yes & Yes & Yes \\
\hline Year FE & Yes & Yes & Yes & Yes & Yes & Yes \\
\hline \# of firms & 6,228 & 7,186 & 9,033 & 5,353 & 6,064 & 7,206 \\
\hline$\#$ of $N$ & 19,075 & 14,601 & 18,979 & 19,622 & 13,274 & 16,156 \\
\hline
\end{tabular}

${ }^{7}$ Specifically, the results are not convenient to compare with the previous research because all analyzes are made for subsamples: (i) financially constrained and financially unconstrained firms; and (ii) firms in weak- and wellgoverned countries. Also, this research focuses on examining the adjustment speed of cash, not its' firm-level determinants. 
Table 2. Optimal Cash Holdings across Financial Constraints and Governance (cont).

\begin{tabular}{|c|c|c|c|c|c|c|}
\hline \multicolumn{7}{|c|}{$\begin{array}{l}\text { Panel B. Governance } \\
\text { Dependent variable: CASH }\end{array}$} \\
\hline & \multicolumn{3}{|c|}{ Firms in Weak-Governed Countries } & \multicolumn{3}{|c|}{ Firms in Well-Governed Countries } \\
\hline & $\overline{P R E}$ & CRISIS & POST & $\overline{P R E}$ & CRISIS & POST \\
\hline Variables & $\begin{array}{l}2001-2006 \\
(7)\end{array}$ & $\begin{array}{l}2007-2009 \\
(8)\end{array}$ & $\begin{array}{l}2010-2015 \\
(9)\end{array}$ & $\begin{array}{l}2001-2006 \\
(10)\end{array}$ & $\begin{array}{l}2007-2009 \\
(11)\end{array}$ & $\begin{array}{l}2010-2015 \\
(12)\end{array}$ \\
\hline$\overline{L . C A S H}$ & $\begin{array}{l}0.570 * * * \\
(0.013)\end{array}$ & $\begin{array}{l}0.438 * * * \\
(0.007)\end{array}$ & $\begin{array}{l}0.427 * * * \\
(0.029)\end{array}$ & $\begin{array}{l}0.462 * * * \\
(0.002)\end{array}$ & $\begin{array}{l}0.437 * * * \\
(0.006)\end{array}$ & $\begin{array}{l}0.532 * * * \\
(0.007)\end{array}$ \\
\hline$\stackrel{\lambda}{\text { Controls }}$ & $43.0 \%$ & $56.2 \%$ & $57.3 \%$ & $53.8 \%$ & $56.3 \%$ & $46.8 \%$ \\
\hline L.SIZE & $\begin{array}{l}-0.011 * * * \\
(0.000)\end{array}$ & $\begin{array}{l}-0.022 * * * \\
(0.003)\end{array}$ & $\begin{array}{l}-0.011 * \\
(0.007)\end{array}$ & $\begin{array}{l}-0.019 * * * \\
(0.000)\end{array}$ & $\begin{array}{l}-0.022 * * * \\
(0.008)\end{array}$ & $\begin{array}{l}-0.015^{*} \\
(0.009)\end{array}$ \\
\hline L.GROW & $\begin{array}{l}0.001 \\
(0.001)\end{array}$ & $\begin{array}{l}0.001 \\
(0.004)\end{array}$ & $\begin{array}{l}0.001 * * * \\
(0.000)\end{array}$ & $\begin{array}{l}0.004 * * * \\
(0.000)\end{array}$ & $\begin{array}{l}0.003 * * * \\
(0.000)\end{array}$ & $\begin{array}{l}0.006 * * * \\
(0.000)\end{array}$ \\
\hline L.VOL & $\begin{array}{l}-1.784 * * * \\
(0.389)\end{array}$ & $\begin{array}{l}6.090 * * \\
(2.588)\end{array}$ & $\begin{array}{l}0.175 \\
(1.645)\end{array}$ & $\begin{array}{l}-2.549 * * * \\
(0.618)\end{array}$ & $\begin{array}{l}7.131 * \\
(3.795)\end{array}$ & $\begin{array}{l}1.773 \\
(1.606)\end{array}$ \\
\hline L.INV & $\begin{array}{l}-0.026 \\
(0.040)\end{array}$ & $\begin{array}{l}-0.014 \\
(0.022)\end{array}$ & $\begin{array}{l}-0.044 \\
(0.003)\end{array}$ & $\begin{array}{l}-0.044 \\
(0.056)\end{array}$ & $\begin{array}{l}0.058 * * * \\
(0.018)\end{array}$ & $\begin{array}{l}-0.020^{*} \\
(0.011)\end{array}$ \\
\hline L.LEV & $\begin{array}{l}0.015 * * \\
(0.007)\end{array}$ & $\begin{array}{l}-0.004^{*} \\
(0.003)\end{array}$ & $\begin{array}{l}-0.015 * * * \\
(0.011)\end{array}$ & $\begin{array}{l}-0.007 \\
(0.012)\end{array}$ & $\begin{array}{l}0.032 * * * \\
(0.008)\end{array}$ & $\begin{array}{l}-0.019 \\
(0.025)\end{array}$ \\
\hline L.NWC & $\begin{array}{l}0.045^{* * * *} \\
(0.003)\end{array}$ & $\begin{array}{l}0.077 * * * \\
(0.008)\end{array}$ & $\begin{array}{l}0.002 \\
(0.014)\end{array}$ & $\begin{array}{l}-0.003 \\
(0.015)\end{array}$ & $\begin{array}{l}0.050 * * * \\
(0.014)\end{array}$ & $\begin{array}{l}-0.043 * * * \\
(0.009)\end{array}$ \\
\hline L.CFA & $\begin{array}{l}-0.015^{* *} \\
(0.007)\end{array}$ & $\begin{array}{l}-0.02 * * \\
(0.011)\end{array}$ & $\begin{array}{l}-0.017 \\
(0.014)\end{array}$ & $\begin{array}{l}0.021 * * * \\
(0.000)\end{array}$ & $\begin{array}{l}0.008 * * * \\
(0.001)\end{array}$ & $\begin{array}{l}0.010 \\
(0.015)\end{array}$ \\
\hline$L . R \& D$ & $\begin{array}{l}-0.125^{* * * *} \\
(0.001)\end{array}$ & $\begin{array}{l}-0.011 * * \\
(0.005)\end{array}$ & $\begin{array}{l}0.007 \\
(0.002)\end{array}$ & $\begin{array}{l}0.013 \\
(0.037)\end{array}$ & $\begin{array}{l}0.147 * * * \\
(0.019)\end{array}$ & $\begin{array}{l}-0.130 * * * \\
(0.029)\end{array}$ \\
\hline Firm FE & Yes & Yes & Yes & Yes & Yes & Yes \\
\hline Year FE & Yes & Yes & Yes & Yes & Yes & Yes \\
\hline \# of firms & 4,569 & 6,022 & 10,672 & 4,335 & 4,642 & 7,589 \\
\hline$\#$ of $N$ & 20,856 & 15,837 & 21,504 & 17,841 & 12,038 & 13,631 \\
\hline
\end{tabular}

Notes: Table 2 reports the adjustment speeds $(\lambda)$ of cash holdings across financial constraints by Panel A and governance by Panel B for the PRE (2001-2006), CRISIS (2007-2009) and POST (2010-2015) periods by employing the LSDVC. Cash holding adjustment speeds $(\lambda)$ are calculated ' $1-$ the coefficient of lagged cash'. The dependent variable is CASH that is the ratio of cash and short- term investments to total assets. The definitions of all variables are presented in Table 1. Robust standard errors are presented in brackets (.). The system GMM initializes the bias correction by employing LSDVC. $* * *, * *$ and $*$ imply statistical significance at $1 \%, 5 \%$ and $10 \%$, respectively.

\section{Conclusions}

This study investigates how optimal cash holdings have changed after the GFC across the variation in financial constraints and governance for the sample 122,787 firm-years in eleven countries which have various ownership structures over the 2001-2015 period. The findings show that constrained firms have faster cash adjustments than unconstrained firms, as confirmed by precautionary motive. Besides, constrained firms decrease less their cash adjustments than unconstrained firms from pre- to the post-GFC period, in which precautionary motive works better. Also, while firms in weak-governed countries have slower cash adjustments than those in well-governed countries before the GFC, it is vice versa during the post-crisis, as supported by agency motive.

This research contributes to the empirical literature by examining the role of financial constraints and governance on optimal cash holdings in the GFC context. In particular, the explanatory power of agency motive and precautionary motive increases after the GFC due to rising adjustment costs during the GFC. As the primary implication for practice, constrained 
and unconstrained firms should consider the possibility of turbulences and their impacts in terms of facing potential difficulties in accessing external finance to direct their investment policies and make cash decisions. As another implication for practice, the sample is a broad range including a variety of governance levels. Investors should consider market imperfections, financial constraints and country governance, as institutional settings, to make more informed and prudent cash policies regarding which firms to invest in.

\section{Acknowledgements}

This paper is one of the chapters of my $\mathrm{PhD}$ dissertation entitled "How have cash holdings changed by the global financial crisis? A cross-country analysis". I thank to the editors and the anonymous referee who have given a detailed feedback. I am grateful to William Megginson and Viet Dang, discussants of the paper at the 2018 FMA-Europe Conference, for their helpful comments and suggestions. I also thank Aydin Ozkan, Yilmaz Yildiz, Ali Yavuz Polat and the supervision team on an earlier version of this paper.

\section{References}

Bates, T. W., Chang, C. H., and Chi, J. D. (2018) Why has the value of cash increased over time?, Journal of Financial and Quantitative Analysis, 1-39.

Blundell, R., and Bond, S. (1998) Initial conditions and moment restrictions in dynamic panel data models, Journal of Econometrics, 87(1), 115-143.

Bruno, G. S. (2005) Estimation and inference in dynamic unbalanced panel-data models with a small number of individuals, Stata Journal, 5(4), 473.

Chen, H. C., Chou, R. K., and Lu, C. L. (2018) Saving for a rainy day: evidence from the 2000 dot-com crash and the 2008 credit crisis, Journal of Corporate Finance, 48, 680-699.

Coldbeck, B., and Ozkan, A. (2018) Comparison of adjustment speeds in target research and development and capital investment: what did the financial crisis of 2007 change, Journal of Business Research, 84, 1-10.

D'Amato, A. (2019) Capital structure, debt maturity, and financial crisis: empirical evidence from SMEs, Small Business Economics, 1-23.

Dang, V. A., Kim, M., and Shin, Y. (2015) In search of robust methods for dynamic panel data models in empirical corporate finance, Journal of Banking \& Finance, 53, 84-98.

Flannery, M. J., and Hankins, K. W. (2013) Estimating dynamic panel models in corporate finance, Journal of Corporate Finance, 19, 1-19.

Kaufmann, D., Kraay, A. and Mastruzzi, M. (2011) The worldwide governance indicators: methodology and analytical issues, Hague Journal on the Rule of Law, 3(2), 220-246.

La Porta, R., Lopez-de-Silanes, F., Shleifer, A., and Vishny, R. W. (2000) Agency problems and dividend policies around the world, The Journal of Finance, 55(1), 1-33.

Lozano, M. B., and Duran, R. F. (2017) Family control and adjustment to the optimal level of cash holding, The European Journal of Finance, 23(3), 266-295.

Martinez-Sola, C., Garcia-Teruel, P. J. and Martinez-Solano, P. (2018) Cash holdings in SMEs: speed of adjustment, growth and financing, Small Business Economics, 51(4), 823-842.

Nguyen, C. (2019) The asymmetry in firms' mechanisms of cash holding adjustments: evidence from the G-5 economies, Review of Quantitative Finance and Accounting, 53(2), 429-463.

Ozkan, A., and Ozkan, N. (2004) Corporate cash holdings: an empirical investigation of UK companies, Journal of Banking \& Finance, 28(9), 2103-2134.

Seifert, B., and Gonenc, H. (2018) The effects of country and firm-level governance on cash management, Journal of International Financial Markets, Institutions and Money, 52, 1-16. 


\section{Appendix A - Additional tables}

Table A1. Sample Distribution and Mean Cash across Country and Year.

\begin{tabular}{|c|c|c|c|c|c|c|c|}
\hline Country & Mean Cash & $\#$ of $\mathrm{N}$ & $\%$ of $\mathrm{N}$ & Year & Mean Cash & $\#$ of $\mathrm{N}$ & $\%$ of $\mathrm{N}$ \\
\hline France & 0.153 & 4,990 & $\overline{4.1}$ & $\overline{2001}$ & 0.157 & 5,986 & 4.9 \\
\hline Germany & 0.180 & 5,292 & 4.3 & 2002 & 0.156 & 6,042 & 4.9 \\
\hline India & 0.072 & 15,177 & 12.4 & 2003 & 0.160 & 6,177 & 5.0 \\
\hline Indonesia & 0.114 & 2,835 & 2.3 & 2004 & 0.173 & 7,702 & 6.3 \\
\hline Italy & 0.126 & 1,685 & 1.4 & 2005 & 0.179 & 8,517 & 6.9 \\
\hline Japan & 0.180 & 33,164 & 27.0 & 2006 & 0.171 & 9,906 & 8.1 \\
\hline Korea & 0.159 & 13,319 & 10.8 & 2007 & 0.166 & 10,121 & 8.2 \\
\hline Netherlands & 0.121 & 1,085 & 0.9 & 2008 & 0.155 & 10,108 & 8.2 \\
\hline Turkey & 0.097 & 2,089 & 1.7 & 2009 & 0.162 & 9,554 & 7.8 \\
\hline UK & 0.187 & 9,426 & 7.7 & 2010 & 0.180 & 8,574 & 7.0 \\
\hline US & 0.222 & 33,725 & 27.5 & 2011 & 0.234 & 1,928 & 1.6 \\
\hline \multirow[t]{5}{*}{ Total } & 0.171 & 122,787 & 100.0 & 2012 & 0.224 & 1,466 & 1.2 \\
\hline & & & & 2013 & 0.173 & 12,219 & 10.0 \\
\hline & & & & 2014 & 0.178 & 12,461 & 10.1 \\
\hline & & & & 2015 & 0.178 & 12,026 & 9.8 \\
\hline & & & & Total & 0.171 & 122,787 & 100.0 \\
\hline
\end{tabular}

Notes: The sample on 122,787 firm-years standing for 14,885 sample firms in eleven countries is retrieved from Worldscope in Datastream International. Table A1 reports the mean of cash and the distribution of the number (\#) of observations $(\mathrm{N})$ and the percentage (\%) of observations across country and year, respectively. Source: Worldscope,

Table A2. Robustness Analyses.

\begin{tabular}{|c|c|c|c|c|c|c|c|c|}
\hline \multicolumn{9}{|c|}{ Dependent variable: CASH } \\
\hline & \multirow{2}{*}{\multicolumn{2}{|c|}{$\begin{array}{l}\text { Financial constraints } \\
\text { Constrained firms }\end{array}$}} & \multirow{2}{*}{\multicolumn{2}{|c|}{ Unconstrained firms }} & \multicolumn{4}{|c|}{ Governance } \\
\hline & & & & & \multicolumn{2}{|c|}{ Weak governance } & \multicolumn{2}{|c|}{ Well governance } \\
\hline & $P R E$ & POST & $\overline{P R E}$ & POST & $P R E$ & POST & $P R E$ & POST \\
\hline \multicolumn{9}{|c|}{ Panel A. Alternative measure of financial constraints (firm size) and governance (Antidirector rights) } \\
\hline L.CASH & $\begin{array}{l}0.451 * * * \\
(0.011)\end{array}$ & $\begin{array}{l}0.524 * * * \\
(0.001)\end{array}$ & $\begin{array}{l}0.647 * * * \\
(0.010)\end{array}$ & $\begin{array}{l}0.820 * * * \\
(0.010)\end{array}$ & $\begin{array}{l}0.489 * * * \\
(0.012)\end{array}$ & $\begin{array}{l}0.597 * * * \\
(0.013)\end{array}$ & $\begin{array}{l}0.454 * * * \\
(0.032)\end{array}$ & $\begin{array}{l}0.567 * * * \\
(0.007)\end{array}$ \\
\hline$\lambda$ & $54.9 \%$ & $47.6 \%$ & $35.3 \%$ & $18.0 \%$ & $51.1 \%$ & $40.3 \%$ & $54.6 \%$ & $43.3 \%$ \\
\hline \multicolumn{9}{|c|}{ Panel B. Sample composition excluding Japan and the US } \\
\hline L.CASH & $\begin{array}{l}0.379^{* * * *} \\
(0.013)\end{array}$ & $\begin{array}{l}0.572 * * * \\
(0.021)\end{array}$ & $\begin{array}{l}0.573^{* * * *} \\
(0.038)\end{array}$ & $\begin{array}{l}0.776^{* * * *} \\
(0.040)\end{array}$ & $\begin{array}{l}0.532^{* * * *} \\
(0.021)\end{array}$ & $\begin{array}{l}0.700 * * * \\
(0.010)\end{array}$ & $\begin{array}{l}0.495 * * * \\
(0.018)\end{array}$ & $\begin{array}{l}0.598 * * * \\
(0.004)\end{array}$ \\
\hline$\lambda$ & $62.1 \%$ & $42.8 \%$ & $42.7 \%$ & $22.4 \%$ & $46.8 \%$ & $30.0 \%$ & $50.5 \%$ & $40.2 \%$ \\
\hline \multicolumn{9}{|c|}{ Panel C. Sample composition excluding India, Japan, Korea, the UK and the US } \\
\hline L.CASH & $\begin{array}{l}0.511 * * * \\
(0.007)\end{array}$ & $\begin{array}{l}0.807 * * * \\
(0.017)\end{array}$ & $\begin{array}{l}0.513 * * * \\
(0.001)\end{array}$ & $\begin{array}{l}0.931 * * * \\
(0.185)\end{array}$ & $\begin{array}{l}0.478^{* * * *} \\
(0.005)\end{array}$ & $\begin{array}{l}0.706 * * * \\
(0.003)\end{array}$ & $\begin{array}{l}0.654 * * * \\
(0.004)\end{array}$ & $\begin{array}{l}0.990 * * * \\
(0.133)\end{array}$ \\
\hline$\lambda$ & $48.9 \%$ & $19.3 \%$ & $48.7 \%$ & $6.9 \%$ & $52.2 \%$ & $29.4 \%$ & $34.6 \%$ & $1.0 \%$ \\
\hline \multicolumn{9}{|c|}{ Panel D. Alternative estimator: the generalized methods of moments (GMM) } \\
\hline L.CASH & $\begin{array}{l}0.489 * * * \\
(0.027)\end{array}$ & $\begin{array}{l}0.541 * * * \\
(0.025)\end{array}$ & $\begin{array}{l}0.697 * * * \\
(0.024)\end{array}$ & $\begin{array}{l}0.725 * * * \\
(0.022)\end{array}$ & $\begin{array}{l}0.634 * * * \\
(0.022)\end{array}$ & $\begin{array}{l}0.628 * * * \\
(0.024)\end{array}$ & $\begin{array}{l}0.538 * * * \\
(0.028)\end{array}$ & $\begin{array}{l}0.600 * * * \\
(0.033)\end{array}$ \\
\hline $\begin{array}{l}\lambda \\
\text { AR (2) test } \\
\text { Hansen test }\end{array}$ & $\begin{array}{c}51.1 \% \\
{[0.634]} \\
t\left[0.000^{\mathrm{a}}\right]\end{array}$ & $\begin{array}{l}45.9 \% \\
{[0.642]} \\
{\left[0.000^{\mathrm{a}}\right]}\end{array}$ & $\begin{array}{l}30.3 \% \\
{[0.467]} \\
{\left[0.000^{\mathrm{a}}\right]}\end{array}$ & $\begin{array}{l}27.5 \% \\
{[0.594]} \\
{\left[0.000^{\mathrm{a}}\right]}\end{array}$ & $\begin{array}{l}36.6 \% \\
{[0.075]} \\
{\left[0.000^{\mathrm{a}}\right]}\end{array}$ & $\begin{array}{l}37.2 \% \\
{[0.367]} \\
{\left[0.000^{\mathrm{a}}\right]}\end{array}$ & $\begin{array}{l}46.2 \% \\
{[0.604]} \\
{\left[0.000^{\mathrm{a}}\right]}\end{array}$ & $\begin{array}{l}40.0 \% \\
{[0.656]} \\
{\left[0.000^{\mathrm{a}}\right]}\end{array}$ \\
\hline \multicolumn{9}{|c|}{ All models include: } \\
\hline Controls & Yes & Yes & Yes & Yes & Yes & Yes & Yes & Yes \\
\hline Firm FE & Yes & Yes & Yes & Yes & Yes & Yes & Yes & Yes \\
\hline Year FE & Yes & Yes & Yes & Yes & Yes & Yes & Yes & Yes \\
\hline
\end{tabular}

Notes: Table A2 presents the results of robustness analyses by four panels. All analyses for PRE and POST periods are repeated (i) by an alternative measure of financial constraints (firm size) and governance (Antidirector rights) in Panel A; (ii) by excluding Japanese and US firms in Panel B; and (iii) by excluding firms in India, Japan, Korea, the UK and the US in Panel C; and (iv) by an alternative estimator: the system GMM in Panel D. P-values, which are presented in brackets [.], of AR(2) and Hansen tests show the reliability of the GMM estimation. For brevity, the coefficients of lagged cash are only reported, but all models include control variables, firm FE and year FE as employed in main analyses. $* * *$ and ${ }^{\mathrm{a}}$ imply the statistical significance at $1 \%$. 
Table A3. Descriptive Statistics.

\begin{tabular}{lrrrrrrr}
\hline \hline Variables & Mean & SD & Min & p25 & Median & p75 & Max \\
\hline CASH t & 0.171 & 0.187 & 0.000 & 0.041 & 0.108 & 0.227 & 1.000 \\
GOV t & 0.957 & 0.591 & -0.930 & 0.759 & 1.217 & 1.308 & 1.909 \\
DPS t-1 & 0.470 & 0.499 & 0.000 & 0.000 & 0.000 & 1.000 & 1.000 \\
SIZE t-1 & 11.688 & 1.848 & 5.224 & 10.441 & 11.200 & 12.759 & 19.912 \\
GROW t-1 & 1.895 & 2.270 & 0.181 & 0.899 & 1.166 & 1.809 & 19.377 \\
VOL t-1 & 0.043 & 0.010 & 0.028 & 0.035 & 0.040 & 0.047 & 0.066 \\
INV t-1 & 0.048 & 0.061 & 0.000 & 0.011 & 0.029 & 0.061 & 0.638 \\
LEV t-1 & 0.239 & 0.212 & 0.000 & 0.052 & 0.202 & 0.368 & 0.962 \\
NWC t-1 & -0.001 & 0.259 & -1.446 & -0.090 & 0.023 & 0.139 & 0.692 \\
CFLOWt-1 & 0.029 & 0.231 & -0.994 & 0.020 & 0.073 & 0.129 & 0.978 \\
R\&D t-1 & 0.027 & 0.072 & 0.000 & 0.000 & 0.000 & 0.015 & 0.606 \\
\hline \hline
\end{tabular}

Notes: Table A3 reports the descriptive statistics across cash ratios and its explanatory variables. Variable definitions are presented in Table 1. The mean, standard deviation (SD), minimum, percentiles of 25, 50 and 75 and maximum values are presented, respectively for each variable. All variables winsorized at the $1 \%$ and $99 \%$ level to overcome outliers. Source: Worldscope and Kaufmann et al. (2011).

Table A4. Correlation Matrix.

\begin{tabular}{|c|c|c|c|c|c|c|c|c|c|c|}
\hline Variables & CASH $\mathrm{t}$ & $\overline{1}$ & 2 & $\overline{3}$ & $\overline{4}$ & 5 & $\overline{6}$ & 7 & $\overline{8}$ & $\overline{9}$ \\
\hline $1 \mathrm{GOVt}$ & $0.219^{\mathrm{a}}$ & & & & & & & & & \\
\hline 2 DPS t-1 & $-0.106^{\mathrm{a}}$ & $-0.042^{\mathrm{a}}$ & & & & & & & & \\
\hline 3 SIZE t-1 & $-0.156^{\mathrm{a}}$ & $0.074^{\mathrm{a}}$ & $0.352^{\mathrm{a}}$ & & & & & & & \\
\hline 4 GROWt-1 & $0.275^{\mathrm{a}}$ & $0.126^{\mathrm{a}}$ & $-0.200^{\mathrm{a}}$ & $-0.224^{\mathrm{a}}$ & & & & & & \\
\hline 5 VOL t-1 & $0.165^{\mathrm{a}}$ & $0.072^{\mathrm{a}}$ & $-0.179^{\mathrm{a}}$ & $-0.162^{\mathrm{a}}$ & $0.121^{\mathrm{a}}$ & & & & & \\
\hline 6 INV t-1 & $-0.150^{\mathrm{a}}$ & $-0.124^{\mathrm{a}}$ & $0.024^{\mathrm{a}}$ & 0.001 & $0.031^{\mathrm{a}}$ & -0.005 & & & & \\
\hline 7 LEV t-1 & $-0.308^{a}$ & $-0.142^{\mathrm{a}}$ & $-0.158^{a}$ & $0.032^{\mathrm{a}}$ & $0.142^{\mathrm{a}}$ & $-0.080^{\mathrm{a}}$ & $0.103^{\mathrm{a}}$ & & & \\
\hline $8 \mathrm{NWC} \mathrm{t-1}$ & $-0.109^{a}$ & $-0.093^{a}$ & $0.188^{\mathrm{a}}$ & $0.008^{\mathrm{a}}$ & $-0.484^{\mathrm{a}}$ & $-0.046^{\mathrm{a}}$ & $-0.048^{a}$ & $-0.425^{\mathrm{a}}$ & & \\
\hline 9 CFLOWt-1 & $-0.199^{a}$ & $-0.122^{\mathrm{a}}$ & $0.366^{\mathrm{a}}$ & $0.213^{\mathrm{a}}$ & $-0.486^{\mathrm{a}}$ & $-0.086^{\mathrm{a}}$ & $0.081^{\mathrm{a}}$ & $-0.231^{\mathrm{a}}$ & $0.474^{\mathrm{a}}$ & \\
\hline $10 \mathrm{R} \& \mathrm{D} \mathrm{t}-1$ & $0.401^{\mathrm{a}}$ & $0.176^{\mathrm{a}}$ & $-0.19^{a}$ & $-0.123^{\mathrm{a}}$ & $0.263^{\mathrm{a}}$ & $0.136^{\mathrm{a}}$ & $-0.068^{a}$ & $-0.092^{\mathrm{a}}$ & $-0.102^{\mathrm{a}}$ & $-0.352^{\mathrm{a}}$ \\
\hline
\end{tabular}

Notes: Table A4 reports the correlation matrices across the cash ratios and its explanatory variables. Variable definitions are presented in Table 1. Without reporting, the variance inflation factor (VIF) values of firm-specific variables are analyzed. It is found that the mean VIF is 1.34 and each VIF value for all variables is smaller than 1.75 (it should be smaller than 10). So, firm-specific variables do not suffer from multicollinearity. a implies a statistical significance at $1 \%$. Source: Worldscope and Kaufmann et al. (2011) 